\title{
Topikal Siklosporin A, Propolis, ve Deksametazonun Korneal Neovaskülarisazyonlu Ratlarda Oksidatif Stres Üzerine Etkileri
}

\section{Effects of the Topical Application of Cyclosporin A, Propolis and Dexamethasone on Oxidative Stress in Rats with Corneal Neovascularization}

\author{
${ }^{1}$ İsa YUVACI, ${ }^{2}$ Hayrullah YAZAR \\ ${ }^{1}$ MD, Department of Ophthalmology, Sakarya University Training and Research Hospital, Sakarya, Turkey \\ ${ }^{2}$ MD, Department of Biochemistry, Sakarya University Training and Research Hospital, Sakarya, Turkey \\ İsa Yuvac1: https://orcid.org/0000-0003-0694-9009 \\ Hayrullah Yazar: https://orcid.org/0000-0001-9447-6322
}

\section{ÖZ}

Amaç: Deneysel kornea neovaskülarizasyonu (KNV) oluşturulmuş ratlarda topikal kornea inhibe edici ajanların toplam antioksidan kapasite (TAK), toplam oksidan kapasite (TOK) ve oksidatif stres indeksi(OSI) düzeyleri üzerindeki etkilerininin karşılaştırılması.

Materyal ve Metot: 35 Wistar erkek rat tedavilere göre 5 gruba ayrıldı. Grup I:\% 0.9 salin, Grup II:\% 0.05 topikal siklosporin A, GrupIII:\% 1 topikal propolis, Grup IV:\% 3 topikal propolis ve GrupV:\% 0.1 deksametazon. KNV, ratların sağ gözlerinde sodyum hidroksit ile oluşturuldu. Bu uygulamadan 24 saat sonra tedaviler başlatıldı. Tüm gruplar 10 gün boyunca günde $3 \mathrm{kez}$ tedavi edildi. Daha sonra tüm ratlardan kan örnekleri alındı. Tüm istatistiksel analizler IBM SPSS for Windows Version 20.0 yazılımı kullanılarak yapıldı.

Bulgular; TAK değerleri sırasıyla 1.32, 1.22, 1.75, 1.27 ve $1.37 \mu \mathrm{mol}$ Trolox equivalent/L idi. TAK değerleri açısından en anlamlı artış Grup 3'te bulundu $(\mathrm{p}=0.041)$. TOK değerleri sırasıyla; 4.80, 6.0, 5.98, 6.09 ve 10,32 mmol $\mathrm{H}_{2} \mathrm{O}_{2}$ equivalent/L. idi. TOK değerleri açısından en anlamlı fark Grup 5'te bulundu ( $\mathrm{p}=0.041)$. OSİ değerleri sirasıyla; 355.39 , 494.63, 346.55, 477.18 ve 746.48 idi. OSİ parametreleri açısından sadece Grup 5'te anlamlı fark ölçüldü $(\mathrm{p}=0.002)$.

Sonuç: Topikal korneal inhibitör ajanlar arasında \% 1'lik propolisin TAK üzerinde önemli etkisinin olduğu, Deksametazon kullanımının OSI'de önemli bir artışa neden olduğu bulundu.

Anahtar Kelimeler: Deksametazon, oksidatif stress, propolis, siklosporin A

\section{ABSTRACT}

Objective: To compare the effects of topical corneal inhibitory agents on total antioxidant capacity (TAC), total oxidant capacity (TOC), and oxidative stress index (OSI) levels in rats with experimentally acquired corneal neovascularization $(\mathrm{CNV})$.

Materials and Methods: 35 Wistar male rats were divided into 5 Groups; Group I: $0.9 \%$ saline, Group II: $0.05 \%$ topical cyclosporine A, Group III: $1 \%$ topical propolis, Group IV: $3 \%$ topical propolis and Group V: $0.1 \%$ dexamethasone. $\mathrm{CNV}$ was formed with sodium hydroxide in the right eyes. All groups were treated 3/day for 10 days. Blood samples were taken from all of the rats.

Results: The TAC of the groups were 1.32, 1.22, 1.75, 1.27, and $1.37 \mu \mathrm{mol}$ Trolox equivalent/L, respectively. The highest statistically significant increase in the TAC parameter was determined in Group III ( $\mathrm{p}=0.041)$. TOC of the groups were $4.80,6.0,5.98,6.09$, and $10,32 \mathrm{mmol}_{2} \mathrm{O}_{2}$ equivalent/ L. The highest statistically significant increment of the TOC parameter was determined in Group V $(\mathrm{p}=0.041)$. OSI in the groups was $355.39,494.63,346.55,477.18$, and 746.48 , respectively. Statistically significant increment of the OSI parameter was determined in GroupV $(\mathrm{p}=0.002)$.

Conclusion: Among these agents, $1 \%$ propolis was found to have the greatest effect on TAC. On the other hand, the use of Dexamethasone has caused a significant increase in OSI.

Keywords: Cyclosporin A, dexamethasone, oxidative stress, propolis
Sorumlu Yazar / Corresponding Author:

İsa Yuvacı

Sakarya University Training and Research Hospital, Ophtalmology Department, Adnan Menderes St. Sağlık Sok. No: 195 Adapazarı Sakarya, Turkey

Phone::+90 44454 00,

Mobile Phone: +905056236936,

E-mail: mdisay@hotmail.com
Yayın Bilgisi / Article Info:

Gönderi Tarihi/ Received: 12/04/2020

Kabul Tarihi/ Accepted: 12/05/2020

Online Yayın Tarihi/ Published: 30/06/2020

Atıf / Cited: Yuvaci I, Yazar H. Effects of the Topical Application of Cyclosporin A, Propolis and Dexamethasone on Oxidative Stress in Rats with Corneal Neovascularization. Online Türk Sağllk Bilimleri Dergisi 2020;5(2):271-280. doi: 10.26453/otjhs.718950 


\section{INTRODUCTION}

Various conditions such as infectious keratitis, corneal trauma, alkali injury, and wearing contact lenses can cause corneal neovascularization (CNV). ${ }^{1}$ ${ }^{-3} \mathrm{CNV}$ can present a serious problem such as glare, photophobia, or visual loss secondary to corneal scarring and lipid deposition. ${ }^{2}$ The main strategy in the treatment of $\mathrm{CNV}$ involves inhibiting angiogenesis.

Topical steroids are the main component in $\mathrm{CNV}$ therapy, Dexamethasone (Dexa) is an analog of synthetic corticosteroids and is a strong antiinflammatory drug. ${ }^{4,5}$ The use of Dexa results in many changes in cellular and humoral immune responses such as reduced expression of certain Matrix metalloproteinases (MMPs) (MMPs-1, -3, -9, $12,-13$ ) and inflammatory cytokines expression (IL$1 \beta$ and IL-6) while it significantly increases MMP$8 .^{6}$ The anti-inflammatory effect of topical dexamethasone is demonstrated via neutrophil infiltrations and the increasing MMP- $8 .^{7}$

Propolis is a natural product produced by honey bees. $3 \%$ and $1 \%$ (aqueous) propolis obtained from an alcohol-free, $70 \%$ propolis extract is consumed in the market as oral liquid. ${ }^{8-11}$ Propolis extract and its fractions, especially artepillin $\mathrm{C}$ and caffeic acid phenyl ester are effective in reducing the secretion of major stimulatory factors involved in cell proliferation and angiogenesis. So far, propolis extract has been a potential candidate as an antiangiogenic agent and can inhibit migration and capillary tube formation. ${ }^{12-16}$

Cyclosporine A ( $\mathrm{Cycl} \mathrm{A})$, isolated from the fungus Tolypocladium inflatum, is an 11-amino-acid polypeptide. Cycl A causes a significant reduction in IL2 which plays a critical role in CNV. ${ }^{17,18}$ Recently, it has been increasingly used for treating CNV that develops following penetrating keratoplasty and chemical burns. ${ }^{19-21}$

Oxidative stress is caused by the imbalance between free radical production and endogenous antioxidant defense mechanisms. Total antioxidant capacity (TAC) measurement, which includes enzymatic and non-enzymatic antioxidants, may provide more valuable evidence to oxidative stress. Total oxidant capacity (TOC) measurement which reflects the whole oxidant state has been improved. Oxidative Stress Index (OSI) is an index that widely used for determining oxidative stress. ${ }^{22}$
The effects of topical agents used in the treatment of CNV on TAC and TOC levels may be associated with various complications. The aim of this study is to compare the effects of topical corneal inhibitory agents on TAC, TOC, and OSI levels in rats with experimentally acquired CNV. As well as the effectiveness of the drugs the low side effects should be considered in the planning of the treatment. To the best of our knowledge, this research is the first of its kind.

\section{MATERIALS AND METHODS}

The study conformed to the Declaration of Helsinki. Experimental procedures for using laboratory animals were approved by the Local Ethics Committee of Abant İzzet Baysal University on 08.01.2016 (Decision no:B.30.2.ABÜ.0.05.05-050.01.04-1).

Thirty-five male Wistar rats were used in this study. All rats were 2 months old and 200-250 grams in weight. They were divided equally and randomly into 5 treatment groups as follows: Group I: isotonic saline $0.9 \%$, Group II: topical $0.05 \%$ cyclosporine A, Group III: topical $1 \%$ propolis, Group IV: topical $3 \%$ propolis and Group V: $0.1 \%$ dexamethasone. 3\% propolis is available as an oral liquid supplement. $1 \%$ propolis was prepared by diluting $3 \%$ propolis under sterile conditions. Before any treatment was applied to the rats, they were put under anesthesia by intramuscular injection of ketamine $\mathrm{HCl}(25 \mathrm{mg} / \mathrm{kg})$ and xylazine hydrochloride $(5 \mathrm{mg} / \mathrm{kg})$. Then, topical proparacaine $\mathrm{HCl}(0.5 \%)$ was dropped onto the right eye of each rat. Subsequently, sodium hydroxidesaturated paper, $3 \mathrm{~mm}$ in diameter, was applied to the central cornea of the right eye of each rat for 20 seconds. The cornea was then washed with $10 \mathrm{~mL}$ of isotonic saline solution. Twenty-four hours after the cornea was washed, the treatments were applied in the right eyes of the rats with $\mathrm{CNV}, 3$ times a day for 10 days. By the end of the 10th day, 1 rat in each group except Group II had died. Blood samples of the rats were subsequently obtained.

Laboratory Tests: All samples were immediately centrifuged at $1500 \mathrm{rpm}$ for 10 minutes to separate the serums. The serums were then stored at $-80{ }^{\circ} \mathrm{C}$ until the analysis. On the day of the analysis, the TAC and TOC levels were examined using a fully automatic analyzer (Architect C16000; Abbott Laboratories, Lake Bluff, IL, USA). Oxidative Stress Index (OSI) is obtained by dividing TOC by TAC. 
Statistical Analysis: Descriptive statistics were calculated using the values obtained from this study and shown as the arithmetic mean and standard deviation. Because the number of rats in most of the groups was under 7, for mean comparisons of values obtained from drug application groups, nonparametric tests were performed directly without doing normality tests. Firstly, Kruskal Wallis variance analysis was conducted. The $p$ values found to be under 0.05 were accepted as statistically significant. Then, Mann Whitney U tests with Bonferroni correction were executed for dual comparisons of drug applications which were found to have statistically significant differences. Because 10 dual comparisons in 5 drug application groups would be made in total, the statistically significant $\mathrm{p}$-value is accepted as under $0.005(0.05 / 10=0.005)$. All statistical analyses were performed using IBM SPSS for Windows Version 20.0 software.

\section{RESULTS}

TAC, TOC, and OSI values of all groups are shown in Table 1.

TAC averages were distributed in $\mu \mathrm{mol}$ Trolox equivalent/L according to groups; Group I: 1.32 , Group II: 1.22, Group III: 1.75, Group IV: 1.27 , Group V: 1.37. TAC results were analyzed and a statistical difference was found between all of the groups ( $p=0,022$, Table 1$)$. According to the TAC parameter, it was determined that the greatest increase for the control group was in Group III (iuue 1). On the other hand, it was found that this increase was not significant ( $p=0.041$, Table 2). There was no significant change in any of the other groups.

The distribution of the TOC mean results, in mmol $\mathrm{H} 2 \mathrm{O} 2$ equivalent/L, for groups was as follows; Group I: 4.80, Group II: 6.00, Group III: 5.98, Group IV: 6.09, Group V: 10.32. There was a significant difference in the TOC mean results between the groups compared to the Kruskal Wallis test ( $p=$ 0.017 , Table 1). According to the TOC parameter, it was seen that the greatest increase was in Group V compared to Group I (Figure 2). However, it was found that this increase was not statistically significant $(\mathrm{p}=0.017$, Table 2). A noticeable increase could not be detected in other groups either (Figure 2).

The mean results of the OSI, which was determined as Arbitrary Units (AU), were as follows according to the groups; Group I: 355.40, Group II: 494.63, Group III: 346.55, Group IV: 477.18, Group V:
746.18. There was a significant difference between the groups ( $p=0.007, \underline{\text { Table } 1})$. On the other hand, only the increase in Group V was statistically significant ( $\mathrm{p}=0.002$, Table 2) (Figure 3).

\section{DISCUSSION AND CONCLUSION}

New studies are being conducted as well as steroids and other medicines being used for CNV treatment. Although sufficient studies that use drugs have been conducted regarding $\mathrm{CNV}$, there are insufficient studies in terms of oxidative stress indicators. Oxidative stress indicators may play a decisive role in the choice of drugs over time.

OSI shows wide variations among individuals and between different population groups. In recent years, studies have revealed the correlation of OSI with many chronic disorders. ${ }^{23}$ TAC and TOC are becoming increasingly used as an index of oxidative stress. Automated approaches are now generally applied for measuring OSI. ${ }^{24}$ This is particularly beneficial given that research has uncovered the correlations of OSI levels with oxidative stress and inflammation. ${ }^{25}$

The most striking finding in our study was the over increasing OSI values in Group V. Considering that the OSI value in the control group was 355,40 , the OSI value of Group V which was 746,48 is frequently used in routine treatment of ophthalmologists. We were unable to find a study in the literature to compare.

In the compilation made by Bakunowicz-Łazarczyka up-to-date information on topical treatment uses for published CNV inhibitors was studied. ${ }^{26}$ In this review, it is seen that there is no research yet on oxidative stress on antiangiogenic topical treatment agents. No research was found on the effects of antiangiogenic topical treatment agents on oxidative stress in the literature review. Thus, our study is the first to focus on this subject.

In a recent study, serum physiological and Dexa treatment options were tested on mice. ${ }^{7}$ They stated that safer and more efficient anti-inflammatory therapies may not decrease all MMPs, since it was demonstrated that MMP-8 can have protective functions during Dexa treatment. Although the control group and the experimental animals used in the study by Bian F. et al. were the same as in our study, their study did not evaluate the effects of Dexa on oxidative stress markers. $^{7}$

In a study, the CNV process was conducted on 52 experimental animals by applying Dexa 4 times a day for 7 days. ${ }^{27}$ Although the OSI has not been studied, 
the results of this study are consistent with those of our study.

In another study, conducted on rats with meningitis, it was mentioned that oxidative stress increased in rats given Dexa according to the control group. ${ }^{28}$ The difference in the mechanisms causing meningitis and CNV creates a different situation in terms of comparison.

In our study, the use of $\% 1$ propolis resulted in oxidative markers being overly effective for the desired effects and less harmful for the side effects. Propolis already can become a chemical, having been increasingly used in pharmacology. ${ }^{29}$ Propolis is thought to make its activity through substances such as artepillin $\mathrm{C}$ and caffeic acid ester in its content. ${ }^{29}$ One of the interesting results of our work is that $3 \%$ propolis and $1 \%$ of propolis activities were different in oxidative stress markers. We have not found any data to explain and to compare this in the literature.

Keshavarz M. et al. reported that propolis is potentially active in CNV and is an antiangiogenic agent, additionally preventing cell migration. ${ }^{30}$ In addition to this information, especially considering the low TAC value and OSI for $1 \%$ propolis, our study supports the effective potent agent qualification that was reported by Keshavarz M. et al. ${ }^{30}$ This is because, in our study, the systemic adverse effect of $1 \%$ propolis did not occur in terms of OSI. Although many different mechanisms lead to $\mathrm{CNV}$, studying only one mechanism can be specified as the limitation of our study.

In conclusion; the significant elevation of the TOC results and OSI in Group $\mathrm{V}$ is a condition that should be considered because of the widespread use of Dexa in clinical practices. The use of Dexa results in many changes in cellular and humoral immune responses. The extent to which these or which cause the increase in OSI can be determined by the work to be done in this regard. Research should be conducted into the influence of Dexa on oxidative stress makers to determine whether steroids have the same influence as Dexa.

The other result that comes to the fore in the study is perhaps the difference between propolis $1 \%$ and $3 \%$, which will be expressed in our literature for the first time. Larger studies are needed.

Ethics Committee Approval: Our study was approved by the Local Ethics Committee of Abant İzzet Baysal University (Date: 08.01.2016, decision
no:b.30.2.ABÜ.0.05.05-050.01.04-1).

Conflict of Interest: No conflict of interest was declared by the authors.

Author Contributions: Concept - IY, HY; Supervision -HY; Materials -HY, IY; Data Collection and Processing - IY, HY; Analysis and Interpretation - HY, IY; Writing - IY.

Peer-review: Externally peer-reviewed.

Acknowledge: This research was supported by $\mathrm{Stj}$. Dr. F.E. Yazar, literature conformity (Bulent Ecevit University, Medical School) and Prof. Dr. O. Karabay, for the statistical study and revising it critically for important intellectual content (Sakarya University Medical School).

\section{REFERENCES}

1. Lee P, Wang CC, Adamis AP. Ocular neovascularization. An epidemiologic review. Surv Ophthalmol. 1998;433:245-269.

2. Alldredge OC, Krachmer JH. Clinical types of corneal transplant rejection their manifestations, frequency, preoperative correlates, and treatment. Arch Ophthalmol. 1981;994:599-604.

3. Chang JH, Gabison EE, Kato T, Azar DT. Corneal neovascularization. Curr Opin Ophthalmol. 2001;124:242-249.

4. Boneham GC, Collin HB. Steroid inhibition of limbal blood and lymphatic vascular cell growth. Curr Eye Res. 1995;14:1-10.

5. Manzano RP, Peyman GA, Khan P, et al. Inhibition of experimental corneal neovascularisation by bevacizumab (Avastin). $\mathrm{Br}$ J Ophthalmol. 2007;91:804-807.

6. Nakao S, Hata Y, Miura M, et al. Dexamethasone inhibits interleukin-1beta-induced corneal neovascularization: role of nuclear factor-kappaBactivated stromal cells in inflammatory angiogenesis. Am J Pathol. 2007;171:1058-1065.

7. Bian F, Wang C, Tukler-Henriksson J, et al. MMP-8 Is Critical for Dexamethasone Therapy in Alkali-Burned Corneas Under Dry Eye Conditions. J Cell Physiol. 2016;231(11):2506-2516. doi: 10.1002/jcp.25364.

8. Marcucci MC. Propolis: chemical composition, biological properties and therapeutic activity. Apidologie. 1995;26:83-99.

9. Nakajima Y, Shimazawa M, Mishima S, Hara H. Water extract of propolis and its main constituents, caffeoylquinic acid derivatives, exert neuroprotective effects via antioxidant actions. 
Life Sci. 2007;80:370-377.

10.Burdock GA. Review of the biological properties and toxicity of bee propolis (Propolis). Food Chem Toxicol. 1988;36:347-363.

11.Hwang HJ, Park HJ, Chung, et al. Inhibitory effects of caffeic acid phenethyl ester on cancer cell metastasis mediated by the down-regulation of matrix metalloproteinase expression in human HT1080 fibrosarcoma cells. J Nutr Biochem. 2006; 17: 356-362.

12.Hepsen IF, Er H, Cekic O. Topically applied water extract of propolis to suppress corneal neovascularization in rabbits. Ophthalmic Res. 1999;31:426-431.

13.Jin UH, Chunga TW, Kanga SK, et al. Caffeic acid phenyl ester in propolis is a strong inhibitor of matrix metalloproteinase-9 and invasion inhibitor: isolation and identification. Clin Chim Acta. 2005;362:57-64.

14.Ahn MR, Kunimasa K, Ohta T, et al. Suppression of tumor-induced angiogenesis by Brazilian propolis: major component artepillin $\mathrm{C}$ inhibits in vitro tube formation and endothelial cell proliferation. Cancer Lett. 2007;252(2):235-243.

15.Kimoto T, Arai Kohguchi M, Aga M, et al. Apoptosis and suppression of tumor growth by artepillin C extracted from Brazilian propolis. Cancer Detect Prev. 1998;22:506-515.

16. Shimizua K, Dasa SK, Babab M, Matsuurac Y, Kanazawaa K. Dietary artepillin C suppresses the formation of aberrant crypt foci induced by azoxymethane in mouse colon. Cancer Lett. 2006;240:135-142.

17.Nussenblatt RB, Palestine AG. Cyclosporine: immunology, pharmacology, and therapeutic uses. Surv Ophthalmol. 1986;31:159-169.

18.Lutty GA, Liu SH, Pendergrast RA. Angiogenic lymphokines of activated $\mathrm{T}$-cell origin. Invest Ophthalmol Vis Sci. 1983;24:1595-1601.

19.Heiligenhaus A, Steuhl KP. Treatment of HSV-1 stromal keratitis with topical cyclosporin A: a pilot study. Graefes Arch Clin Exp Ophthalmol. 1999;237:435-438.

20.Lipman RM, Epstein RJ, Hendricks RL. Suppression of corneal neovascularization with cyclosporine. Arch Ophthalmol. 1992;110: 405407.

21.Benelli U, Ross JR, Nardi M, Klintworth GK. Corneal neovascularization induced by xenografts or chemical cautery. Inhibition by cyclosporin A.
Invest Ophthalmol Vis Sci. 1997;38:274-282.

22.Erel O. A novel automated method to measure total antioxidant response against potent free radical reactions. Clin Biochem. 2004;37:112121.

23.Ates I, Ozkayar N, Topcuoglu C, Dede F. Relationship between oxidative stress parameters and asymptomatic organ damage in hypertensive patients without diabetes mellitus. Scand Cardiovasc J. 2015;49(5):249-56. doi: 10.3109/14017431.2015.1060355.

24.Gunay S, Taskin A, Eser I, Yalcin S, Yalcin F. Oxidative stress and DNA damage due to onelung ventilation. Ann Ital Chir. 2018;89:24-29.

25. Khazan M, Hedayati M, Robati RM, Riahi SM, Nasiri S. Impaired oxidative status as a potential predictor in clinical manifestations of herpes zoster. J Med Virol. 2018;28. doi: 10.1002/ jmv. 25204.

26.Bakunowicz-Łazarczyk A, Urban B. Assessment of therapeutic options for reducing alkali burninduced corneal neovascularization and inflammation. Adv Med Sci. 2015;3;61(1):101112. doi: 10.1016/j.advms.2015.10.003.

27.Mirabelli P, Peebo BB, Xeroudaki M, Koulikovska M, Lagali N. Early effects of dexamethasone and anti-VEGF therapy in an inflammatory corneal neovascularization model. Exp Eye Res. 2014;125:118-27. doi: 10.1016/ j.exer.2014.06.006.

28.Barichello T, Santos AL, Silvestre C, et al. Dexamethasone treatment reverses cognitive impairment but increases brain oxidative stress in rats submitted to pneumococcal meningitis. Oxid Med Cell Longev. 2011:173035. doi: 10.1155/2011/173035.

29.Fasolo D, Bergold AM, von Poser G, Teixeira HF. Determination of benzophenones in lipophilic extract of Brazilian red propolis, nanotechnology-based product and porcine skin and mucosa: Analytical and bioanalytical assays. J Pharm Biomed Anal. 2016;124:57-66. doi: 10.1016/j.jpba.2016.02.018.

30.Keshavarz M, Mostafaie A, Mansouri K, Shakiba Y, Motlagh HR. Inhibition of corneal neovascularization with propolis extract. Arch Med Res. 2009:40(1):59-61. 
Table 1. The mean values for total antioxidant capacity, total oxidant capacity, oxidative stress index.

\begin{tabular}{|c|c|c|c|c|c|c|}
\hline & Group I (n:6) & $\begin{array}{c}\text { Group II } \\
\text { (n:7) }\end{array}$ & $\begin{array}{c}\text { Group III } \\
\text { (n:6) }\end{array}$ & $\begin{array}{c}\text { Group IV } \\
\text { (n:6) }\end{array}$ & $\begin{array}{c}\text { Group V } \\
\text { (n:6) }\end{array}$ & $p$ \\
\hline TAC & $1,32 \pm 0,20$ & $1,22 \pm 0,08$ & $1,75 \pm 0,43$ & $1,27 \pm 0,07$ & $1,37 \pm 0,16$ & $0,022^{*}$ \\
\hline TOS & $4,80 \pm 2,21$ & $6,00 \pm 2,38$ & $5,98 \pm 1,86$ & $6,09 \pm 2,13$ & $10,32 \pm 2,48$ & $0,017^{*}$ \\
\hline OSI & $355,40 \pm 107,06$ & $494,63 \pm 192,19$ & $346,55 \pm 82,85$ & $477,18 \pm 154,66$ & $746,48 \pm 101,53$ & $0,007^{*}$ \\
\hline
\end{tabular}

*p<0.005. TAC: Total antioxidant capacity; TOC: Total oxidant capacity, OSI: Oxidative stress index. 
Table 2. $P$ values for total antioxidant capacity, total oxidant capacity, oxidative stress index.

\begin{tabular}{|l|c|c|c|c|}
\hline & Group 2 & Group 3 & Group 4 & Group 5 \\
\hline TAC & 0,945 & 0,041 & 0,818 & 0,589 \\
\hline TOC & 0,181 & 0,132 & 0,180 & 0,009 \\
\hline OSI & 0,138 & 0,818 & 0,132 & $0,002 *$ \\
\hline
\end{tabular}

* $p<0.005$. $p$ values obtained by comparison of treatment groups with the control group. TAC: Total antioxidant capacity, TOC: Total oxidant capacity, OSI: Oxidative stress index. 


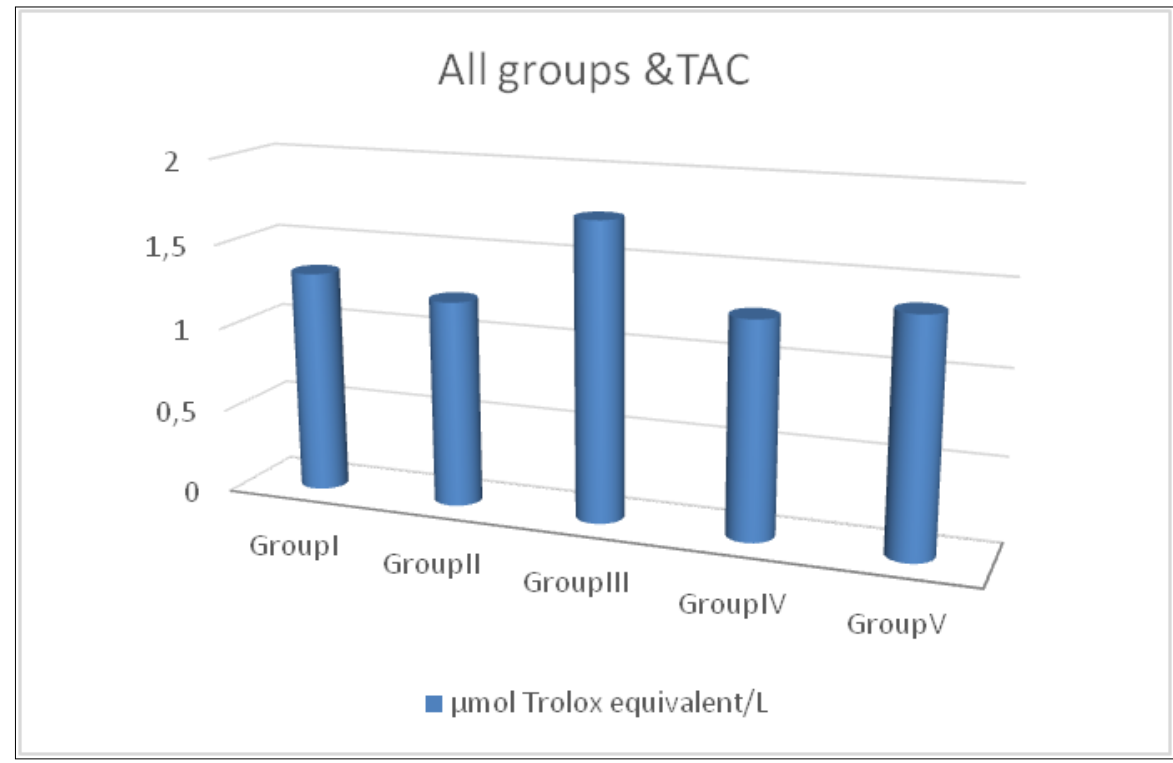

Figure 1. Total antioxidant capacity distributions in all groups. 


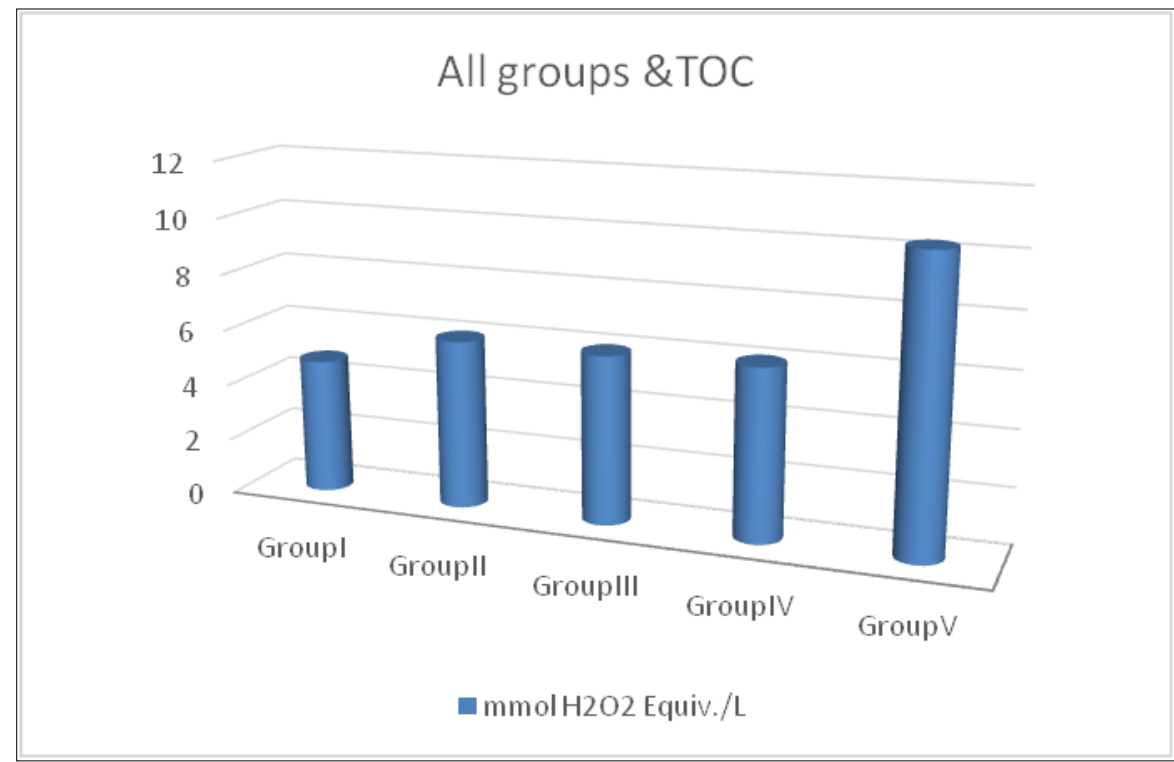

Figure 2. Total oxidant capacity distributions in all groups. 


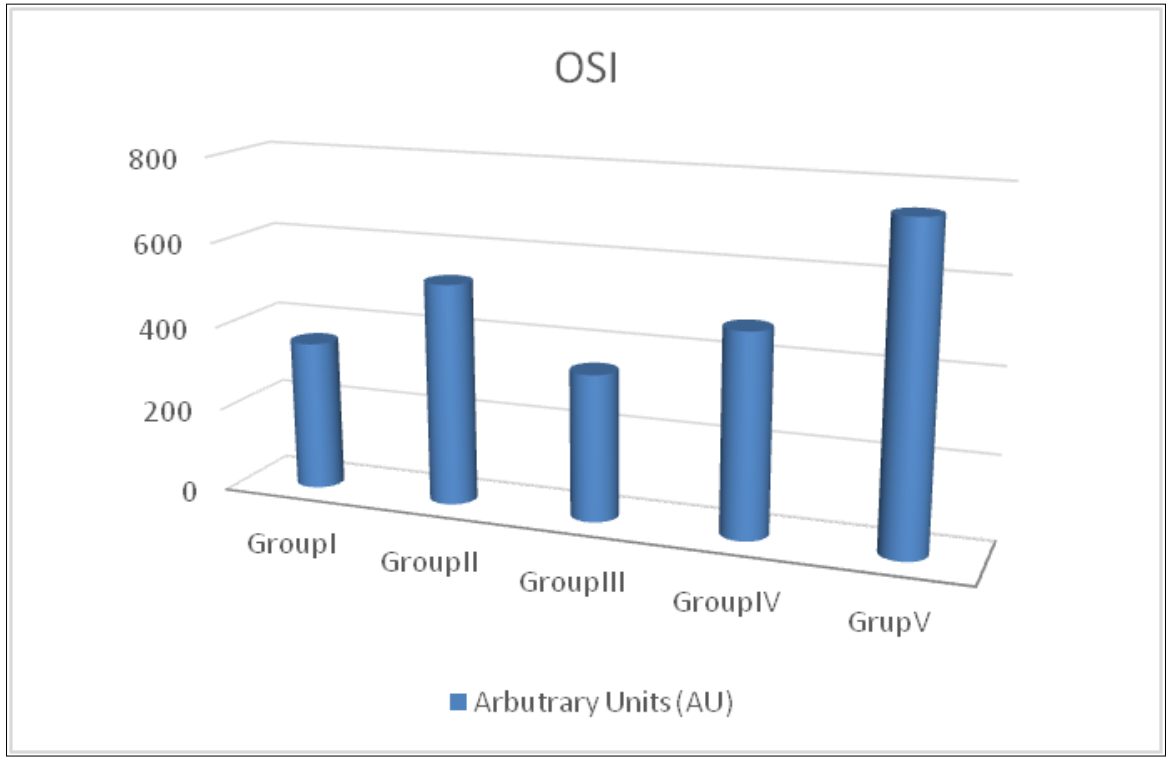

Figure 3. Oxidative stress index distributions in all groups. 